\title{
PENGEMBANGAN SMART BRANDING SEBAGAI LANGKAH AWAL MENUJU TERWUJUDNYA SMART CITY DI KOTA TOMOHON
}

\author{
Reynold Patabuga \\ Email:reyhemingway99@gmail.com \\ Ilmu Pemerintahan \\ Ilmu Sosial dan Politik \\ Universitas Muhammadiyah Yogyakarta \\ Eko Priyo Purnomo \\ Email:eko@umy.ac.id \\ Ilmu Sosial dan Politik \\ Universitas Muhammadiyah Yogyakarta \\ Aulia Nur Kasiwi \\ Email:aulianurkasiwi@gmail.com \\ Ilmu Sosial dan Politik \\ Universitas Muhammadiyah Yogyakarta
}

\begin{abstract}
ABSTRAK
Penelitian ini memakai metode penelitian yang bersifat kualitatif, yang mana menurut (Creswell, 2010) adalah kegiatan yang kemudian berdasar atas suatu telaah yang komprehensif terhadap suatu objek, yang mana merupakan data yang berbentuk kata demi kata dan data tersebutlah yang akhirnya akan di interpretasikan oleh peneliti secara subjektif dengan kritis. Sedangkan teori yang di pakai di sini adalah teori dari Yuli yang saya kutip dari (Siti Zumroh Nur Ivani, 2015) di mana ia mengemukakan bahwa dalam pemasaran yang pintar (smart branding) dalam kota cerdas (smart city) haruslah memenuhi beberapa kriteria yang di antaranya yakni: Pertama, mempunyai ide atau sebuah simbol yang kemudian menjadi ikon dari sebuah tempat (attributes); Kedua, mengandung pesan yang hendak di sampaikan yang mana hal tersebut akan menjadi pengingat bagi orang tentang tempat itu (message); Ketiga, mempunyai sebuah keunikan atau sebuah perbedaan yang kemudian itu mengkhususkan tempat tersebut ketimbang tempat lain sehingga bisa menjadi suatu nilai jual yang tinggi (differentiation); Keempat, dan yang terakhir yakni bagaimana caranya di sana bisa kemudian di temukan suatu hal yang barangkali bisa di bilang memikat bagi orang dari tempat yang berbeda untuk memutuskan diri agar datang, lebih lebih tinggal di tempat tersebut (ambassadorship). Dari penelitian ini peneliti menyimpulkan bahwa strategi pemasaran pintar (smart branding) di kota Tomohon sudah baik adanya, dengan memanfaatkan potensi wisata yang bukan hanya alam akan tetapi dengan kerukunan atau bisa di bilang pluralisme yang melampaui sekat sekat yang biasanya di tabukan, malahan di jadikan sebuah ikon kota yang di sana mudah di ingat dan sekaligus menjadi pesan damai kepada para wisatawannya. Saran yang perlu kiranya di kemukakan di sini adalah bahwa kota Tomohon bisa sebenarnya mendapatkan keuntungan materil dari pemasaran pintar yang di jalankan di sana jika saja dengan baik di kelola oleh pemerintah kota, seturut dengan itu oleh masyarakat yang secara baik menerimanya.
\end{abstract}

Kata Kunci : Smart Branding, Smart City, Attributes, Differentiation

\section{ABSTRACT}

This study uses qualitative research methods, which according to (Creswell, 2010) are activities that are then based on a comprehensive study of an object, which is data in the form of the word for word. The data is what will ultimately be interpreted by researchers subjectively critically. While the theory used here is a 
theory from Yuli that I quoted from (Siti Zumroh Nur Ivani, 2015) in which he stated that in smart marketing (smart branding) in a smart city (smart city) must meet several criteria, including namely: First, have an idea or a symbol which then becomes an icon of a place (attributes); Second, it contains a message to be conveyed which will be a reminder for people about the site (news); Third, it has a uniqueness or a difference which then specifies the place rather than other places so that it can become a high selling value (differentiation); Fourth, and finally how can there be found something that might be said to be attractive to people from different places to decide themselves to come, more stay in the site (ambassadorship). From this study the researchers concluded that the smart marketing strategy (smart branding) in the city of Tomohon is already good, by utilizing the potential of tourism that is not only natural but with harmony or can be said of pluralism that goes beyond the bulkhead of the divisions that are usually taboo, even made the city's icon is easily remembered and at the same time a message of peace to the tourists. The suggestion that needs to be put forward here is that the city of Tomohon can benefit materially from smart marketing that is run there if only it is well managed by the city government, according to that by the people who are well received.

Keywords: Smart Branding, Smart City, Attributes, Differentiation

\section{PENDAHULUAN}

Sebagai sebuah kota yang kemudian dalam beberapa waktu lalu sudah di canangkan oleh pemerintah pusat sebagai salah satu kota tujuan atau yang di berikan arahan untuk mengembangkan suatu pembangunan yang bersandarkan dan berstandarkan kota pintar atau kota cerdas (dalam hal ini sering di sebut dengan smart city), kota Tomohon yang merupakan salah satu kota yang secara geografis berada di sudut utara pulau Sulawesi menjadi menarik untuk di bicarakan, lebih lebih untuk di teliti perkembagannya, oleh karena seperti yang sudah di sebutkan di atas bahwa memang kota Tomohon sendiri masuk dalam target seratus kota di Indonesia yang di proyeksikan atau di rencanakan pada tahun 2024 mesti sudah menerapkan apa yang di bilang dengan pembangunan berkelanjutan atas dasar konsep pembangunan yang dalam padanan kata dalam bahasa Indonesia kota pintar atau kota cerdas (smart city) (Liputan6.com, 2019). Selanjutnya, dalam pengembangan pembangunan yang berdiri atas konsep atau rumusan kota cerdas (smart city) salah satu aspeknya yang kemudian di nilai sangat dan akan sangat menunjang kehadiran pembangunan dan pengembangan kota yang berkelanjutan, yang sehingga itu bisa menyebabkan berbagai keuntungan atau feed back di dapatkan oleh penerap atau kota yang menggunakannya dalam segi ekonomi adalah branding atau pemasaran yang pintar (dalam hal ini sering di sebut dengan smart branding) (I Wayan Widana \& Gede Sri Darma, 2018). Di mana selain itu pemasaran pintar yang di terapkan dalam sebuah kota bukan semata mata hanya untuk di gunakan sebagai cara untuk meraup keuntungan ekonomi, akan tetapi menjadi salah satu lumbung yang mana merupakan sebuah manifestasi dari pada identitas yang bakal atau di maksudkan oleh pemerintah kota bagi kota yang hendak di majukan taraf pengenalannya mulai 
dari lokal, regional hingga sampai pada aras nasional maupun internasional, sehingga itu kota tersebut seturut dengan pengembangan yang ada dapat di kenal dengan baik oleh kalangan wisatawan maupun bagi referensi acuan bagi berbagai macam kebutuhan yang nantinya juga akan berdampak baik bagi kota, pemerintahnya, dan seturut dengan itu warga dan masyarakat kota setempat (I Wayan Widana \& Gede Sri Darma, 2018).

Oleh karena model pembangunan kota cerdas (smart city) saat ini telah dan tengah menjadi salah satu wacana dan diskursus aktif di berbagai macam disiplin ilmu atau bisa di katakan bahwa diskursus ini telah menjadi suatu diskursus lintas disiplin ilmudan karenanya juga berarti diskusi mengenai kota cerdas (smart city) menjadi sangat menarik dan mau tidak mau mesti di bahas dalam lingkup kajian ekonomi, politik dan budaya itu sendiri. Dalam membahas bagaimana pemasaran pintar (smart branding) yang di canangkan oleh pemerintah kota Tomohon, tentu saja bisa kita tilik dari apa yang menjadi tujuan utama dari gagasan kota cerdas (smart city) yang termuat dalam visi dan misi kota Tomohon di dalam atau yang tercantum di laman website resmi pemerintah kota Tomohon sendiri (Tomohon, n.d.). Bahwa benar kota Tomohon sedang merencanakan pembangunan yang di mana kota cerdas (smart city) di sini akan lebih di sasar atau lebih di sesuaikan dengan potensi kota Tomohon yang mempunyai daya tarik tersendiri di dalam aspek wisata alam dan wisata kulinernya serta banyak lagi hal lain yang kemudian dalam program kota Tomohon memproyeksikan bahwa kelak kota Tomohon akan di jadikan kota wisata kelas dunia (Tomohon, n.d.). Selain itu, bukan saja kota Tomohon sebenarnya yang tengah gencar melalukan pembangunan dalam hal pembangunan kota cerdas (smart city) di utara Sulawesi. Manado pun yang merupakan Ibu Kota dari pada provinsi Sulawesi Utara bahkan memproyeksikan diri atau bahkan mengklaim dalam kurun waktu yang cukup singkat, atau lebih spesifik lagi pada tahun 2021 nanti Manado sudah menjadi kota cerdas dengan berbagai penerapan program serta kerja kebijakan yang kian di arahkan sesuai dengan konsep kota cerdas (smart city), seperti halnya yang di kemukakan dalam penelitian yang di laksanakan oleh para akademisi yang berasal dari salah satu universitas ternama di dataran pulau Sulawesi sendiri yakni Universitas Sam Ratulangi bahwa lewat studi yang mereka lakukan, mereka merasa perlu dalam lingkup kajian akademik menyoal kota cerdas (smart city) di Manado untuk menerapkan model pembangunan gedung apa yang mereka sebut dengan model gedung atau bangunan vertikultur (Poluan, Gosal, \& Wuisang, 2016). 
Dengan kata lain, bahwa usaha dan upaya dari pada kota Tomohon dalam hal mengembangkan pembangunan atas dasar dan landasan kota cerdas (smart city) bukan hanya sendirian di timur Indonesia. Akan tetapi dengan adanya upaya demi upaya yang juga muncul dari tetangga kota dan bahkan saudara kota sendiri dari satu daerah yang sama, kiranya akan memberikan infus yang baik atau semangat yang lebih lagi bagi pemerintah kota juga sekaligus masyarakat kota Tomohon (Poluan et al., 2016). Lebih jauh, studi yang di lakukan oleh para intelektual di Makassar yang sama seperti kota Manado sendiri, berasal dari tanah Sulawesi, kemudian mengungkapkan bahwa pendapat dari pada masyarakat luas terkait dengan penerapan konsep pembangunan kota cerdas (smart city) ini sangatlah mampu untuk di terima keadaannya dan bahkan di rasa sangat membantu masyarakat kota Makassar sendiri dalam hal pelayanan dan akses terhadap pelayanan publik yang di berikan oleh pemerintah kota terhadap mereka (Saptadi et al., 2018). Lebih lanjut, jika melihat apa yang di tulis oleh (Saptadi et al., 2018) berarti mengisyarakatkan bahwa masyarakat kota sendiri telah mempunyai kesadaran, akan hal tentang pentingnya penerapan konsep ini dalam pembangunan serta bagaimana mereka sebenarnya bisa mendapatkan keuntungan dari pada infus dukungan yang mereka berikan kepada pemerintah kota sendiri. Ada juga bukti penelitian yang hampir serupa mengenai bagaimana sebenarnya teknologi informasi dan komunikasi (Information Comunnication and Technology) di manfaatkan dalam hal pembangunan daerah atau kota, yang mana kota tersebut ialah kota yang menjadi Ibu Kota negara kita: Jakarta, dan dari sana melalui pemeringkatan ternyata lewat penggunaan teknologi tersebut kota bisa dengan konsisten mempertahankan peringkatnya, dan bukan hanya sekadar mempertahankan, tetapi juga menjadi kota yang terbaik oleh sebab pemanfaatan teknologi dalam hal pelayanan dan pelaksanaan pemerintahan di sana (Tampubolon, 2016).

Ada pula penelitian yang kemudian menyasar aspek kerja sama atau dalam diskursus pembangunan berkelanjutan seringkali di kata dengan colabortive action, yang mana mengikut sertakan banyak pihak di luar lingkaran pemerintah, sehingga para aktor di luar dari pada pemerintah ini bisa untuk berperan aktif dalam pembangunan atau program kerja yang di rencanakan oleh pemerintah (Dhimas Andisca, 2016). Di mana lewat penelitian itu ia mendapatkan bahwa melalui kerja sama antar pemerintah kota Surabaya dengan beberapa aktor lainnya, bisa terjadi atau bisa terwujud suatu pembangunan atas dasar kota cerdas (smart city) 
yang mana di bangun secara bersama sama sehingga dalam tanggung jawabnya dan rasa puas serta memilikinya sudah di pupuk sejak awal pembangunan tersebut (Dhimas Andisca, 2016). Adapun penelitian yang di laksanakan di kota Tanjungpinang yang mana, ia mendapati bahwa di sana lewat metode analisis yang di gunakan oleh penyusun artikel tersebut, bahwa di sana sangatlah di perlukan sebuah perencanaan yang kiranya sudah siap dengan baik serta cara mengintegrasikan program pembangunan dengan sebanyak banyaknya aktor yang mana peran sertanya dapat memudahkan kerja kerja yang akan di lakukan oleh pemerintah, sehingga dalam menentukan bagaimana pembangunan bisa berjalan dengan baik dan benar kiranya mesti berpegang teguh pada unsur unsur yang sifatnya memadukan kerja antar aktor dan penikmat kebijakan atau apa yang saya sebut tadi dengan kolaborasi (Darmawan, 2018).

Selain hal tersebut ada juga yang mengemukakan dalam penelitian menyoal website tentang kota Manado sendiri, menilai bahwa dengan adanya website tersebut pemerintah kota (dalam hal ini pemerintah kota Manado) meski pun belum sempurna namun, sudah cukup baik dalam hal menerapkan transparansi atau keterbukaan informasi kepada publik sehingga untuk itu di nilai bahwa kota Manado atau pemerintah kota Manado sendiri sudah cukup tangkas dan baik dalam membangun Manado menuju kota cerdas (smart city) dengan memanfaatkan website atau internet mereka bisa menyasar setiap keluhan publik yang sekiranya sangat urgen untuk di dapatkan akan tetapi lantaran kerap terkendala masalah jarak dan waktu, kemudian akhirnya tidak bisa di dapat, yang mana oleh karen kehadiran website tersebut masyarakat setempat sangat terbantu dan begitu juga dengan pemerintah dalam melaksanakan kerja kerjanya di lapangan maupun lewat dunia maya yang sekarang sudah menjadi lapangan kedua dari pada kerja kerja pelayanan publik (Kanter, 2015). Lalu ada penelitian, yang di lakukan di daerah Sumenep yang kemudian menggagas bagaimana daerah wisata atau sektor wisata di kabupaten Sumenep akan di olah sedemikian rupa untuk kemudian memajukan sektor tersebut atas dasar konsep suatu pembangunan yang mampu menjaga ekologi dan juga seturut dengan itu lingkungan yang kemudian berlandaskan konsep kota cerdas (smart city) di mana penulis mengemukakan bahwa program yang ada di sana sudah bisa di katakana baik, dan bagaimana pemerintah kabupaten dengan tangkas dan tanggap untuk kemudian melakukan kolaborasi dengan aktor aktor yang kiranya bisa di ajak terlibat dengan pemerintah dalam menjalakan program pembangunan wisata yang merupakan daya tarik utama kabupaten Sumenep sendiri, dan dengan itu juga menjamin 
bahwa keadaan ekonomi di sana bisa di tingkatkan untuk kemudian memajukan perekonomian kabupaten seturut dengan itu juga masyarakat kabupaten tersebut (Alfiyah, 2019).

\section{METODE PENELITIAN}

Penelitian yang akan di lakukakan ini nantinya akan menggunakan metode penelitian yang bersifat kualitatif, yang mana menurut (Creswell, 2010) adalah kegiatan yang kemudian berdasar atas suatu telaah yang komprehensif terhadap suatu objek, yang mana merupakan data yang berbentuk kata demi kata dan data tersebutlah yang akhirnya akan di interpretasikan oleh peneliti secara subjektif dengan kritis. Di mana model penelitian seperti ini di pilih oleh penulis oleh karena objek penelitian yang di ambil adalah apa yang berkaitan dengan tindakan atau laku manusia serta dampaknya, yang seturut dengan itu juga berarti berada dalam dimensi sosial. Sedangkan teori yang di pakai di sini untuk menganalisis bagaimana pengembangan pemasaran pintar di kota Tomohon (smart branding) sendiri menggunakan teori dari Yuli yang saya kutip dari (Siti Zumroh Nur Ivani, 2015) di mana ia mengemukakan bahwa dalam pemasaran yang pintar (smart branding) dalam kota cerdas (smart city) haruslah memenuhi beberapa kriteria yang di antaranya yakni: Pertama, mempunyai ide atau sebuah simbol yang kemudian menjadi ikon dari sebuah tempat (attributes); Kedua, mengandung pesan yang hendak di sampaikan yang mana hal tersebut akan menjadi pengingat bagi orang tentang tempat itu (message); Ketiga, mempunyai sebuah keunikan atau sebuah perbedaan yang kemudian itu mengkhususkan tempat tersebut ketimbang tempat lain sehingga bisa menjadi suatu nilai jual yang tinggi (differentiation); Keempat, dan yang terakhir yakni bagaimana caranya di sana bisa kemudian di temukan suatu hal yang barangkali bisa di bilang memikat bagi orang dari tempat yang berbeda untuk memutuskan diri agar datang, lebih lebih tinggal di tempat tersebut (ambassadorship).

\section{HASIL DAN PEMBAHASAN}

\section{A. STRATEGI BRANDING}

Seperti yang kita ketahui sebelumnya bahwa kota Tomohon memang sudah di canangkan oleh pemerintah pusat (dalam hal ini para elite di Jakarta) untuk menjadi salah satu kota di antara 100 kota yang kemudian di proyeksikan atau di rencanakan pada tahun 2024 mampu menjadi kota terdepan untuk menjadi acuan sekaligus memberi kemajuan dari segala aspek kehidupan bagi masyarakat yang kotanya tersebut mendapat sebuah kehormatan menikmati bantuan untuk di 
semangati membangun kota menuju kota cerdas (smart city) (Liputan6.com, 2019) Selain hal tersebut ada juga yang mengemukakan dalam penelitian menyoal website tentang kota Manado sendiri, menilai bahwa dengan adanya website tersebut pemerintah kota (dalam hal ini pemerintah kota Manado) meski pun belum sempurna namun, sudah cukup baik dalam hal menerapkan transparansi atau keterbukaan informasi kepada publik sehingga untuk itu di nilai bahwa kota Manado atau pemerintah kota Manado sendiri sudah cukup tangkas dan baik dalam membangun Manado menuju kota cerdas (smart city) dengan memanfaatkan website atau internet mereka bisa menyasar setiap keluhan publik yang sekiranya sangat urgen untuk di dapatkan akan tetapi lantaran kerap terkendala masalah jarak dan waktu, kemudian akhirnya tidak bisa di dapat, yang mana oleh karen kehadiran website tersebut masyarakat setempat sangat terbantu dan begitu juga dengan pemerintah dalam melaksanakan kerja kerjanya di lapangan maupun lewat dunia maya yang sekarang sudah menjadi lapangan kedua dari pada kerja kerja pelayanan publik (Kanter, 2015). Lalu ada penelitian, yang di lakukan di daerah Sumenep yang kemudian menggagas bagaimana daerah wisata atau sektor wisata di kabupaten Sumenep akan di olah sedemikian rupa untuk kemudian memajukan sektor tersebut atas dasar konsep suatu pembangunan yang mampu menjaga ekologi dan juga seturut dengan itu lingkungan yang kemudian berlandaskan konsep kota cerdas (smart city) di mana penulis mengemukakan bahwa program yang ada di sana sudah bisa di katakana baik, dan bagaimana pemerintah kabupaten dengan tangkas dan tanggap untuk kemudian melakukan kolaborasi dengan aktor aktor yang kiranya bisa di ajak terlibat dengan pemerintah dalam menjalakan program pembangunan wisata yang merupakan daya tarik utama kabupaten Sumenep sendiri, dan dengan itu juga menjamin bahwa keadaan ekonomi di sana bisa di tingkatkan untuk kemudian memajukan perekonomian kabupaten seturut dengan itu juga masyarakat kabupaten tersebut (Alfiyah, 2019).

Dalam konsep kota cerdas yang tengah di bangun oleh kota atau pemerintah kota Tomohon adalah sangat penting kiranya kita melihat bagaimana dan apa yang hendak di sampaikan oleh pemerintah dalam hal ini mengenai pemasaran yang pintar (smart branding) di kota Tomohon. Jika kita merujuk pada website pemerintah kota Tomohon maka di sana kita akan menemukan bahwa yang menjadi daya jual dari kota Tomohon menurut pemerintah kota adalah bagaimana sektor wisata (Tomohon, n.d.). Di mana yang di maksud dengan wisata di sana bukan hanya mengenai wisata alam, akan tetapi wisata di sana merupakan sebuah konsep yang kemudian 
berupaya di promosikan oleh pemerintah kota dalam hal bagaimana kerukunan umat antara agama sampai pada perbedaan etnisitas di sana yang kemudian di pelihara secara terus menerus oleh pemerintah kota dan untuk itu pula dalam pengembangan kota cerdas (smart city) di tomohon sekaligus di manfaatkan oleh pemerintah menjadi sebuah ikon dari kota di utara pulau Sulawesi ini (Tomohon, n.d.). Hal tersebut sebenarnya bukan hal baru lagi dalam kenyataan sehari hari di Sulawesi Utara sendiri, di mana kota Manado pun seturut dengan daerah daerah yang lain sebenarnya sudah melakukan hal yang sama dengan kota Tomohon di mana faktor kerukunan itu menjadi ikonik dari kota tersebut (Lukow, 2013). Namun berbeda hal nya dengan kota Tomohon, kota Manado sendiri tidak mencanangkan itu dalam arah pengembangan pemasaran pintar (smart branding) mereka, di mana potensi tersebut memang ada, namun rupa rupanya belum di sadari betul oleh pemerintah kota bahwa sanya hal tersebut bisa di jadikan sebuah branding atau pemasaran kota yang sebenarnya merupakan ikon yang paling mungkin dan paling dekat dengan kultur atau budaya di sana.

Dengan melihat penelitian yang kemudian menyasar aspek kerja sama atau dalam diskursus pembangunan berkelanjutan seringkali di kata dengan colabortive action, yang mana mengikut sertakan banyak pihak di luar lingkaran pemerintah, sehingga para aktor di luar dari pada pemerintah ini bisa untuk berperan aktif dalam pembangunan atau program kerja yang di rencanakan oleh pemerintah (Dhimas Andisca, 2016). Di mana lewat penelitian itu ia mendapatkan bahwa melalui kerja sama antar pemerintah kota Surabaya dengan beberapa aktor lainnya, bisa terjadi atau bisa terwujud suatu pembangunan atas dasar kota cerdas (smart city) yang mana di bangun secara bersama sama sehingga dalam tanggung jawabnya dan rasa puas serta memilikinya sudah di pupuk sejak awal pembangunan tersebut (Dhimas Andisca, 2016). Adapun penelitian yang di laksanakan di kota Tanjungpinang yang mana, ia mendapati bahwa di sana lewat metode analisis yang di gunakan oleh penyusun artikel tersebut, bahwa di sana sangatlah di perlukan sebuah perencanaan yang kiranya sudah siap dengan baik serta cara mengintegrasikan program pembangunan dengan sebanyak banyaknya aktor yang mana peran sertanya dapat memudahkan kerja kerja yang akan di lakukan oleh pemerintah, sehingga dalam menentukan bagaimana pembangunan bisa berjalan dengan baik dan benar kiranya mesti berpegang teguh pada unsur unsur yang sifatnya memadukan kerja antar aktor dan penikmat kebijakan atau apa yang saya sebut tadi dengan kolaborasi (Darmawan, 2018). 


\section{B. KEUNTUNGAN DARI BRANDING}

Keuntungan dari pemasaran pintar, rupa rupanya memang menjadi menarik untuk di bahas di sini. Sebelumnya memang sudah saya kemukakan dengan berdasarkan penelitian yang di lakukan oleh para akademisi yang meneliti soal keuntungan dari pemasaran pintar (smart branding) ini, bahwa selain kota tersebut berkembang dan di kenal melalui branding yang di bangun, ialah keuntungan ekonomi sendiri memang menjadi tujuan utama dari bagaimana kota membangun citranya kepada masyarakat luar atau pun bisa di katakan turis di luar. Bahwa benar kota Tomohon sedang merencanakan pembangunan yang di mana kota cerdas (smart city) di sini akan lebih di sasar atau lebih di sesuaikan dengan potensi kota Tomohon yang mempunyai daya tarik tersendiri di dalam aspek wisata alam dan wisata kulinernya serta banyak lagi hal lain yang kemudian dalam program kota Tomohon memproyeksikan bahwa kelak kota Tomohon akan di jadikan kota wisata kelas dunia (Tomohon, n.d.). Selain itu, bukan saja kota Tomohon sebenarnya yang tengah gencar melalukan pembangunan dalam hal pembangunan kota cerdas (smart city) di utara Sulawesi. Manado pun yang merupakan Ibu Kota dari pada provinsi Sulawesi Utara bahkan memproyeksikan diri atau bahkan mengklaim dalam kurun waktu yang cukup singkat, atau lebih spesifik lagi pada tahun 2021 nanti Manado sudah menjadi kota cerdas dengan berbagai penerapan program serta kerja kebijakan yang kian di arahkan sesuai dengan konsep kota cerdas (smart city), seperti halnya yang di kemukakan dalam penelitian yang di laksanakan oleh para akademisi yang berasal dari salah satu universitas ternama di dataran pulau Sulawesi sendiri yakni Universitas Sam Ratulangi bahwa lewat studi yang mereka lakukan, mereka merasa perlu dalam lingkup kajian akademik menyoal kota cerdas (smart city) di Manado untuk menerapkan model pembangunan gedung apa yang mereka sebut dengan model gedung atau bangunan vertikultur (Poluan et al., 2016).

Dengan kata lain, bahwa usaha dan upaya dari pada kota Tomohon dalam hal mengembangkan pembangunan atas dasar dan landasan kota cerdas (smart city) bukan hanya sendirian di timur Indonesia. Akan tetapi dengan adanya upaya demi upaya yang juga muncul dari tetangga kota dan bahkan saudara kota sendiri dari satu daerah yang sama, kiranya akan memberikan infus yang baik atau semangat yang lebih lagi bagi pemerintah kota juga sekaligus masyarakat kota Tomohon (Poluan et al., 2016). Lebih jauh, studi yang di lakukan oleh para intelektual di Makassar yang sama seperti kota Manado sendiri, berasal dari tanah Sulawesi, 
kemudian mengungkapkan bahwa pendapat dari pada masyarakat luas terkait dengan penerapan konsep pembangunan kota cerdas (smart city) ini sangatlah mampu untuk di terima keadaannya dan bahkan di rasa sangat membantu masyarakat kota Makassar sendiri dalam hal pelayanan dan akses terhadap pelayanan publik yang di berikan oleh pemerintah kota terhadap mereka (Saptadi et al., 2018). Lebih lanjut, jika melihat apa yang di tulis oleh (Saptadi et al., 2018) berarti mengisyarakatkan bahwa masyarakat kota sendiri telah mempunyai kesadaran, akan hal tentang pentingnya penerapan konsep ini dalam pembangunan serta bagaimana mereka sebenarnya bisa mendapatkan keuntungan dari pada infus dukungan yang mereka berikan kepada pemerintah kota sendiri. Ada juga bukti penelitian yang hampir serupa mengenai bagaimana sebenarnya teknologi informasi dan komunikasi (Information Comunnication and Technology) di manfaatkan dalam hal pembangunan daerah atau kota, yang mana kota tersebut ialah kota yang menjadi Ibu Kota negara kita: Jakarta, dan dari sana melalui pemeringkatan ternyata lewat penggunaan teknologi tersebut kota bisa dengan konsisten mempertahankan peringkatnya, dan bukan hanya sekadar mempertahankan, tetapi juga menjadi kota yang terbaik oleh sebab pemanfaatan teknologi dalam hal pelayanan dan pelaksanaan pemerintahan di sana (Tampubolon, 2016). Bahwa kota Tomohon bisa sebenarnya mendapatkan keuntungan materil dari pemasaran pintar yang di jalankan di sana jika saja dengan baik di kelola oleh pemerintah kota, seturut dengan itu oleh masyarakat yang secara baik menerimanya.

\section{KESIMPULAN DAN SARAN}

Dari penelitian di atas peneliti menyimpulkan bahwa strategi pemasaran pintar (smart branding) di kota Tomohon sudah baik adanya, dengan memanfaatkan potensi wisata yang bukan hanya alam akan tetapi dengan kerukunan atau bisa di bilang pluralisme yang melampaui sekat sekat yang biasanya di tabukan, malahan di jadikan sebuah ikon kota yang di sana mudah di ingat dan sekaligus menjadi pesan damai kepada para wisatawannya. Saran yang perlu kiranya di kemukakan di sini adalah bahwa kota Tomohon bisa sebenarnya mendapatkan keuntungan materil dari pemasaran pintar yang di jalankan di sana jika saja dengan baik di kelola oleh pemerintah kota, seturut dengan itu oleh masyarakat yang secara baik menerimanya. 


\section{DAFTAR PUSTAKA}

Alfiyah, N. I. (2019). Upaya Peningkatan Daya Tarik Wisata di Kabupaten Sumenep melalui Smart City System, 1(1).

Creswell, J. W. (2010). Research Design: Pendekatan Kualitatif, Kuantitatif, dan Mixed. Yogyakarta: Pustaka Pelajar. Yogyakarta: Pustaka Pelajar.

Darmawan, E. (2018). PERKEMBANGAN SMART CITY KOTA TANJUNGPINANG. Kemudi: Jurnal Ilmu Pemerintahan, 2(02), 60-78.

Dhimas Andisca. (2016). ANALISIS KERJASAMA PEMERINTAH DAERAH DKI JAKARTA DENGAN YAYASAN DHARMARANYA TUJU ENAM DALAM PEMBANGUNAN TAMAN PINTAR PULOGADUNG. Universitas Diponegoro.

I Wayan Widana \& Gede Sri Darma. (2018). Branding Denpasar Smart City Guna Meningkatkan Kunjungan Wisatawan. Jurnal Manajemen Dan Bisnis, 15(1).

Kanter, C. H. (2015). Peran Website Pemerintah Kota Manado Dalam Mendukung Terwujudnya Good Governance Role of Manado'S Government Website in Supporting. Jurnal Penelitian Komunikasi Dan Opini Publik, 19(3), 197-212.

Liputan6.com. (2019). Pemerintah Targetkan 100 Kota Berkonsep Smart City di 2024. 22 Agustus 2019. https://doi.org/10.17509/wafi.v2i1.7022

Lukow, S. (2013). Eksistensi Good Governance Dalam Sistem Pemerintahan Daerah di Kota Manado. Jurnal Hukum Universitas Sam Ratulangi, 1(5), 130-142. https://doi.org/10.5897/AJB11.124

Poluan, V. S., Gosal, P. H., \& Wuisang, C. E. V. (2016). GEDUNG VERTIKULTUR DI MANADO ' BANGUNAN HEMAT ENERGI ,' 32-41.

Saptadi, N. T. S., Sampe, F., Chyan, P., Teknik, J., Fakultas, I., Informasi, T., ... Makassar, J. (2018). Analisis terhadap persepsi masyarakat makassar dalam upaya untuk mewujudkan tata kelola smart city 1,3, 7(1), 34-42.

Siti Zumroh Nur Ivani. (2015). Pengaruh City Branding “Enjoy Jakarta” Terhadap Citra Kota dan Keputusan Berkunjung Youth Traveler ke Jakarta. UIN Syarif Hidayatullah Jakarta.

Tampubolon, L. P. D. (2016). PEMERINGKATAN E-GOVERNMENT INDONESIA (PEGI) DAN PEMANFAATAN TEKNOLOGI INFORMASI DI DKI JAKARTA. Jurnal Sistem Informasi (JSI), 8(2), 1121-1132.

Tomohon. (n.d.). Visi Dan Misi. Retrieved from https://tomohon.go.id/visi-dan-misi/ 